\title{
El documental, entre definiciones e indefiniciones
}

\section{The Documentary, Between Definitions and Indefinitions}

\author{
José Rojas Bez \\ Facultad de Artes de los Medios Audiovisuales, Universidad de las Artes \\ de Cuba (ISA). La Habana, Cuba. \\ rojasbez@hotmail.com
}

\section{Resumen}

En este ensayo se reflexiona sobre el documental mirado como género del arte cinematográfico. Se propone una definición suya correlacionada con los otros dos géneros primordiales del cine (ficción y animación): sus factores comunes y análogos así como sus diferencias. También analiza semejanzas y diferencias en los diversos usos, instituciones y valores del registro documental -arte fílmico, periodismo y didáctica- y manifestaciones como el falso documental, sin olvidar los filmes animados que reconstruyen hechos y memorias verídicas, a menudo confundidos con el cine documental (los géneros no se definen a partir de la veracidad o falsedad del tema sino de sus modos de hacer). Todo ello se imbrica en un sistema conceptual estético, de la teoría general del arte (teatro, literatura, pintura, etc.) y particularmente del cine.

Palabras clave: cine documental, falso-documental, cine, géneros cinematográficos, medios de comunicación, estética, teoría del arte, imagen.

\section{Abstract}

This essay reflects on the documentary regarded like kind of the movie art. It propose a definition of this genre correlated with the other two cardinal genres (the movies of fiction and the movies of animation): His common and analogous factors as well as his differences. Also it examine similarities and differences in the various uses, institutions and values of the documentary record -cinema art, journalism and didactics- and manifestations as the false documentary, without forgetting the movies of animation that reconstruct facts and truthful memoirs, often confused falsely with the documentary movies (the genres cannot be defined by veracity or falseness of the theme but of his modes of doing). It all intertwines in a esthetic conceptual system, of the theory of the art (plays, novels, painting...) and particularly of the cinema.

Keywords: Documentary cinema, False-Documentary cinema, Cinema, Movie genres, Mass media, Aesthetics, Theory of art, Image. 
Los discípulos, que sólo veían ríos en los ríos y árboles en los árboles -todo como distinto: sólo lo diverso en lo Uno- emprendieron el camino de la liberación de Maya y del Karma; y dejaron de ver los ríos como ríos y los árboles como árboles -todo como lo mismo: sólo lo Uno en lo diverso. La mayoría se quedó perdida en la nueva Ilusión. Pero pocos siguieron con sacrificio y cordura, podían ver de nuevo ríos como ríos y árboles como árboles. Descubrieron la Realidad Suprema: Lo diverso en lo Uno y lo Uno en lo diverso.

Parábola Zen

¿Puede uno definir -deslindar y referir con exactitud y validez universal- un ámbito de manifestaciones tan plurales y, a menudo, ambivalentes y subjetivas como el documental, sobre todo en estos tiempos en que algún sector de la postmodernidad, muy trasnochado y pleno de diletantismo (sin un ápice de la fecundidad del vivido por Oscar Wilde y Baudelaire) abjura de definiciones y sistemas conceptuales, por incapacidad o por pereza y sin advertir que no son lo mismo sistemas teóricos que políticos y sociales? ¿Es posible y, en todo caso, deseable y conveniente el ejercicio de definir; o habríamos de considerar ya agotadas las pautas desbrozadas por tantos maestros del saber como Sócrates y Aristóteles, Tomás de Aquino y Bacon, Descartes, Kant, Hegel, Ayer y otros capaces de las más sutiles distinciones y propuestas?

Apostamos a favor, y no porque neguemos los riesgos conceptuales que siempre ha habido sobre todo en los extremos, los excesos en que sí se han anquilosado a menudo los rigoristas a ultranzas; ni dejemos de abrazar gustosos las suavidades de contorno que reclaman todas las concepciones y acercamientos mentales a la realidad (otro concepto espinoso, que siempre tomaremos con cuidado, respetando determinaciones y salvedades previas), en especial y en nuestro caso, a las realidades artísticas.

Asumimos y defendemos el ejercicio de deslindes y de rigurosidad conceptual con plena conciencia de las múltiples perspectivas emergentes en cualquier clase de correlaciones y, por ende, en las artísticas generales y en las genéricas más específicas; perspectivas y correlaciones tan necesarias y efectivas como a menudo opacas: existe el sur porque hay un norte, de lo contrario, no habría ni norte ni sur; ni arriba ni abajo, grande o pequeño, caliente y frío. Asimismo, conscientes de que importa el lugar desde donde se mire o evalúe. Si fácil es percatarse a veces de los árboles y otras sentir el bosque; difícil resulta llegar al final del camino y vivenciar a la vez el bosque en la multiplicidad de árboles y la singularidad de cada árbol en el bosque.

Existe el género documental, y es definible o sólidamente concebible, sí, porque hay otros géneros (otros dos primordiales: ficción y animación) e híbridos entre ellos; 
de lo contrario ni siquiera hubieran nacido las denominaciones de género y menos aún de documental; lo cual nos hacer volver a la cuestión del mirar sistémicamente ${ }^{1}$.

Por otro lado, podemos hablar de documental de manera más o menos imprecisa o difusa, en más de un sentido, desde diversas disciplinas o perspectivas (periodismo, pedagogía, biología y otras) cuyas debidas distinciones suelen quedar omitidas en algunos discursos. A ellas nos veremos obligados a remitirnos en ocasiones, por cuestión de sistema y deslindes (para no perdernos en los mencionados equívocos), pero enfocaremos nuestra mirada hacia donde vemos la mayor riqueza del documental, hacia su concepción artística o, de modo más general, estética.

Específicamente, nos interesa o, mejor, nos centraremos en el documental como género del cine, ese complejo ámbito que podemos definir cabal y actualizadamente como arte de la sucesión coherente de imágenes audiovisuales recreadas mediante una superficie y una matriz ${ }^{2}$.

Ello implica, en primera instancia, el vislumbre de sus correlaciones con el ámbito general de lo estético, con el más particular o determinado mundo del arte y, en especial, con el cine como conjunto de manifestaciones artísticas más determinadas aún.

Además, nos esforzamos en no perder nunca la conciencia de que, si bien imbricadas y correlativas, no son idénticas estas cuatro preguntas: ¿Qué es el documental, de modo general, como concepto y práctica universalizadas?, ¿Es posible asegurar infaliblemente siempre que esto es un documental?, ¿Es todo documental una obra artística? y ¿Recepciono siempre un documental (o un filme de ficción, o un animado) con la mayor riqueza conceptual, sentimental y de perspectivas posibles?

\section{Una premisa etimológica}

Comencemos por lo más simple e inmediato, las etimologías y el sentido común. Sí, sí, claro, lo sabemos, siempre fallido, desde antes de que creyésemos que la Tierra era plana; pero una guía previa a definiciones y experimentos, como enseñan personas tan

1 Aunque no debiera ser necesario para el interlocutor ya avisado en estos temas, aclaramos que hemos asumido términos de las modernas disciplinas (ya no tan modernas) que no se ha incorporado aún al Diccionario de la Real Academia pero se potencian como imprescindibles. Entre ellos, sistémico, aquello que alude a la reflexión de acuerdo con sistemas, sus conceptos y relaciones, entre otros factores. No es lo mismo ya decir búsquedas sistémicas (alusivas al objeto y cualidad de las consideraciones) que decir búsquedas sistemáticas (alusivas sólo a la cualidad de las búsquedas). Asimismo, cualquier semiólogo, hermeneuta o narratólogo conoce el necesario uso de los términos recepcionar y ficcional, nada idénticoa a recibir o percibir ni a ficticio; como cualquier pedagogo conoce las distinciones entre la enseñanza problémica y una enseñanza problemática. Respetando y reconociendo el necesario tradicionalismo de la Academia, también respetamos las necesarias innovaciones terminológicas de las disciplinas especializadas. Se nos ocurre aquí, de inmediato que, después de todo, ello se armoniza perfectamente con el espíritu general de este ensayo: realizar nuevas propuestas cuando sean necesarias, a la vez que, también, cuando sea justo, apuntalamos, con viejos y nuevos argumentos, lo ya establecido.

2 Trabajamos desde Artes, cine videotape: límites y confluencias (Holguín 1987), pasando por un período de maduración (Cuadernos Cinematográficos 9, 1995) hasta hoy (Pasaje al arte del cine 2013) en esta concepción y definición cabal y actualizada de cine que, lógicamente, implica una mirada en sistema a los distintos géneros, a los recursos expresivos y a las matrices de este arte, además de su historia y actualidad. 
lógicas como Russell y Wittgenstein. Riesgosa e imprecisa, mas guía e indicadora en alguna medida; he ahí la etimología: documental se asocia a documento y documentar.

Adoptemos una guía inicial. Luego desbrozaremos imprecisiones y equívocos. Según serios diccionarios, digamos, el de la Real Academia Española, “documento" es:

(Del lat. documentum)

1. m. Diploma, carta, relación u otro escrito que ilustra acerca de algún hecho, principalmente de los históricos.

2. m. Escrito en que constan datos fidedignos o susceptibles de ser empleados como tales para probar algo.

3. m. desus. Instrucción que se da a alguien en cualquier materia, y particularmente aviso y consejo para apartarle de obrar mal.

\section{auténtico.}

1. m. Der. El que está autorizado o legalizado.

\section{$\sim$ privado.}

1. m. Der. El que, autorizado por las partes interesadas, pero no por funcionario competente, prueba contra quien lo escribe o sus herederos.

$\sim$ público.

1. m. Der. El que, autorizado por funcionario para ello competente, acredita los hechos que refiere y su fecha ${ }^{3}$.

Evidentemente, las acepciones 1 y 2 poseen la mayor relevancia para nuestro tema: "ilustra acerca de algún hecho, principalmente de los históricos", "constan datos fidedignos". En efecto, lo que llamamos cine documental nació y está infundido por tales marcas genéricas, formales y espirituales: ilustrar hechos con datos fidedignos.

Pero -vivimos conscientes de los innumerables "peros"- aflora la necesidad de precisiones cuantitativas y cualitativas, formales y de apreciación. En el documental no sólo constan datos (que también pueden atestiguarse en el filme más ficcional), sino que prevalecen, predominan o está construido en relación con ellos y, por otra parte, no es condición suficiente que ilustre hechos, ni siquiera históricos, como también suelen hacerlo los buenos biopics y los llamados filmes históricos. En muy buena medida, los filmes de ficción, la novelística, el arte todo... documentan; así como, a la inversa, el más positivista y pragmático texto de historia constituye un relato con todo cuanto ello implica de puntos de vista y subjetividad.

Siguiendo el sentido común y una experiencia primaria, el documental, entonces, ilustra, refiere hechos reales mediante una construcción (obra, estructura) a base de, con el predominio y la propuesta de datos fidedignos.

Ahora bien, avanzando un poco más en busca de precisión, se trata de un registro. También podrán entrar en juego otros conceptos y vocablos, como toma y filmación;

3 dle. rae.es/?id=E4EdgX1. 
mas, en fin, un registro fílmico (donde con registro fílmico, y no fotográfico, subrayamos que existen medios no sólo analógicos sino también digitales para realizar tal registro).

Guiados por el impreciso sentido común, alcanzaríamos una aproximación al documental como información o documento realizado predominantemente en base al registro fílmico de una realidad inmediata o dada auténticamente y colmado, claro está, por la propuesta de la veracidad de lo mostrado o de su discurso. Pero, ¿hasta dónde, con qué matices e implicaciones puede sostenerse dicha concepción?

\section{El documental entre lo difuso, lo informativo y lo artístico}

No faltan definiciones del documental, algunas veces apuntando hacia las rigurosas categorías lógicas o como modos personales de idearlo; por ejemplo, la que nos ofrece Etienne Souriau en El universo fílmico, sobre la base de "la presentación de seres o cosas existentes positivamente en la realidad afílmica" (64).

Tampoco faltan los más abarcadores y hondos estudios específicos sobre el documental, donde figura el ya clásico de Bill Nichols, La representación de la realidad. Cuestiones y conceptos sobre el documental, quien no llega a darnos una de estas definiciones cabales aunque sí reflexiona sabiamente sobre tres modos fundamentales de concebirlo: desde la perspectiva del realizador, desde la propiamente textual y desde el público (realizador-texto-público); evidentemente influido (sin hacerlo del todo explícito) por las actuales teorías literarias, del arte y, generalmente, semióticas, hermenéuticas y la recepción, con sus tres estadios y niveles básicos para los análisis: autor-obra-recepción ${ }^{4}$.

Totalmente deudores e inspirados por estos y otros dilectos analistas, nos gustaría añadir de momento una nueva triple perspectiva o, quizás mejor, disposición y espiritualidad con que se asume (se produce, distribuye y recepciona) habitualmente el documental: la información "pura" (sentido difuso, sin mayores atributos), la información "predominante" (información que puede preocuparse por otros valores, digamos el estético) y la información "subsumida" en el predominio de la situación estética siguiendo determinaciones institucionales que, como toda institución (intención, destino y situación) artística, considera al conocimiento y la comunicación como dos de las múltiples propiedades y funciones de la actividad artística cabal. Algo similar a cuando hablamos de escritura o texto escrito vaga y generalmente, de modo difuso o impreciso con relación a enunciados más específicos como escrito o texto científico, teórico, coloquial, poético o literario; o, tomando ahora ejemplo del universo plástico, cuando decimos producir trazos de modo difuso respecto a trazar señales gráficas o a realizar dibujos y grabados plenamente entendidos como arte.

4 Véase especialmente el capítulo El dominio del documental (31-63 de la edición referida en la bibliografía). 
Siempre habremos de contar -aunque fuese implícita, subyacentemente-con esos tres modos, determinados, entre otros factores, por cómo concebimos y con qué designios realizamos ese producto audiovisual de superficie y matriz que nos habla de algo (personas, animales, cosas, naturaleza... hasta de sí mismo, autorreflexivamente) con la mediación formal del registro directo o inmediato.

En sentido difuso -que, lamentablemente, demasiado a menudo se usa como suficiente cuando debiese haber mayores calificativos o precisiones en el uso del término documental-simplemente se llama documental a todo registro fílmico directo de la realidad positiva o inmediata, de la realidad dada ya de antemano a nuestras construcciones fílmicas; y se omiten calificativos y funciones relacionadas con sus fines, propiedades e instituciones precisas. Así, se ignoran diferencias entre lo llanamente comunicativo, didáctico-docente o periodístico (noticias o informaciones simples, entrevistas, reportajes, crónicas... documentales informativos) y lo cabalmente artístico (el documental como forma genérica del arte de la sucesión coherente de imágenes audiovisuales recreadas mediante una superficie y una matriz, como definimos al cine en general), con todas sus connotaciones estéticas e institucionales.

¿Nos acercamos de un modo difuso, sin muchas determinaciones, sin disposiciones marcadas? Bueno, sabemos que ello es casi imposible, pero nada obsta, siguiendo un lenguaje leguleyo, para que lo aceptemos como posible, en especial si no estamos preparados para la situación o no tenemos sensibilidad para lo estéticocinematográfico. También en cine existe el equivalente del ciego para la plástica y el sordo o de oídos duros para la música.

¿Lo hacemos con un espíritu francamente gnoseológico, epistefílico, sin mayores búsquedas y deseos que ese saber que nos ofrecen los conocidos (válidos y admirables en sus fines e instituciones) documentales sobre el hombre y la tierra, los agujeros de gusanos y cuanto magnífico reportaje o, en general, informativo pueda haber? Estimulados por un legítimo saber, podemos satisfacernos en esos medios de saber y no reclamar otras experiencias (placer audiovisual, dramaturgias...) que pueden estar más o menos presentes aunque supeditadas mediáticamente y no en cuanto fines.

$\mathrm{O}$, ¿nos insertamos en la institución-disposición arte y buscamos o asumimos la situación estética, esa que privilegia los sentimientos y valores estéticos que, aclarémoslo, subrayémoslo, no contradicen sino subsumen la comunicación y el saber entendidos en hondo y sutil modo? A ello volveremos luego necesariamente.

Perspectiva difusa, perspectiva informativa y perspectiva estética (o artística) son predisposiciones y asunciones que ameritan considerarse y cuya indefinición a menudo hace imprecisas o insuficientes las reflexiones sobre el documental: ¿Qué documental? ¿Cualquier documental? O, ¿hablamos del documental como arte, con otras palabras, del documental como género artístico-cinematográfico?

Pronunciemos aquí, para ir sembrando motivaciones e inquietudes, dos frases: falso documental y cine de animación; dos conceptos que aluden desde el primer momento a la complejidad de un universo, el artístico, que acepta y aprecia el juego 
ilusorio de "verdad-mentira" y "representación-registro directo", inconcebible como forma o raramente apreciable en el otro universo (el puramente informativo). He aquí también, como temprano adelanto, la advertencia sobre cómo el complejo universo artístico-cinematográfico suele reducirse, en pobres consideraciones teóricas y comparaciones, a lo binario, documental-ficción, cuando posee los atributos artístico-formales cardinales, en cuanto cine, de lo ternario: documental-ficción-animación. Mas, no hay por qué apresurarse demasiado, primero fijémonos bien en el siguiente parangón:

\begin{tabular}{|l|l|}
\hline INSTITUCIÓN & PERSPECTIVA DOMINANTE \\
\hline $\begin{array}{l}\text { TV, Internet y demás medios } \\
\text { informativos y comunicativos } \\
\text { audiovisuales modernos. }\end{array}$ & $\begin{array}{l}\text { La información - El concepto - El saber } \\
\text { - La gnosis. Asume otras pero subordina- } \\
\text { das, subsumidas en estas. También puede } \\
\text { contar con segmentos (espacios fílmicos, } \\
\text { etc.) dedicados a la transmisión de obras } \\
\text { fílmicas plenamente concebidas como arte; } \\
\text { pero, siempre la mediación y el medio. }\end{array}$ \\
\hline Cine & $\begin{array}{l}\text { Estética y, más estrechamente artística: } \\
\text { Conjunción de fines y funciones múltiples: } \\
\text { saber, conocimiento, comunicación, creati- } \\
\text { vidad, juego, placer... }\end{array}$ \\
\hline
\end{tabular}

\section{El arte del documental}

Si añadimos exigencias, deslindes a nuestra experiencia con los documentales, pueden vislumbrarse atributos que los cualifican para una recepción estética o propiamente artística.

Se conoce suficientemente que la recepción estética (la aprehensión sensible de los fenómenos humanos y del universo) o, con mayor particularidad, ciertas cualidades y disposiciones de lo estético (lo bello, lo trágico, lo cómico, lo sublime) suelen manifestarse en todos los ámbitos de la vida humana, por ende, en los productos del hombre (desde el diseño de los artículos que usamos, los automóviles y herramientas hasta las más complejas ceremonias y actividades).

Verdad de Perogrullo: aquí se incluyen los productos mediáticos, incluso los marcadamente didáctico-científicos, que no soslayan la elegancia, la belleza, las lides de la dramaturgia y otras buenas cualidades y categorías, sin que sean sus fines prioritarios, antes bien, subordinados, justamente relegados en pos del certero, preciso y eficaz decir, del transmitir ideas, enseñanzas, saber. Tienen su campo y su razón de 
ser, como los buenos textos didácticos, los diarios informativos, las cartas, telegramas, mensajes de twiter y demás medios para decirnos algo.

Pero el arte o, mejor, cada arte tiene asimismo sus razones de ser y -también verdad de Perogrullo- existe el arte cinematográfico y, el documental o cierta clase de documental como ámbito y serie de productos en ese gran universo del arte cinematográfico, aunque a menudo la identidad (o negligencia para la diversidad) de nombres o vocablos, entre otros factores, lejos de favorecer la distinción contribuye a la confusión.

Pues sí, no vulgaricemos los auténticos recelos contra definiciones, distinciones y sistemas. Los excesos taxonómicos y el esquematismo son deplorables... y las inexistencias o las incapacidades para discernir auténticos contornos y matices de lo existente, la diversidad y singularidad de los árboles en el encanto del bosque son otro extremo lamentable: documentales marcadamente informativos, ilustradores de verdades (o mentiras manipuladas) a expensas o para doblegar a favor de dicha función todas las demás, no se identifican con documentales genuinamente artísticos, afanosos de inscribirse en las instituciones, espacios y recepciones propiamente artísticas.

La diferencia es tan radical y las semejanzas tan firmes también como la de estas líneas respecto a la poesía o, en general, la literatura y el buen texto teatral (todo palabras, palabras, pero cuánto quisiera este autor poseer el don de la poesía aunque conoce y utiliza muchas palabras); o la de los ruidos de la calle respecto a la música (sonidos, sonidos). Poesía o texto conceptual y música o sonidos ambientales son ejemplos que ayudan a ver las diferencias (y semejanzas) entre el documental concebido como pura o predominante información, medio de expresión, simple registro y memoria, y el documental concebido como arte: registros, filmaciones, filmaciones, filmaciones... con diferentes cualidades y sentidos.

Podemos hablar, sí, y es el que más nos interesa precisar aquí, del documental como arte, del documental concebido (ideado, realizado y exhibido) como arte, o sea, actividad humana en mayor o menor grado institucionalizada con el fin de propiciar la situación estética, la aprehensión sensible del universo humano en concordancia con lo bello, lo cómico, lo trágico, lo sublime y demás categorías del mismo o orden; donde las estructuras significantes, las formas valen por sí mismas; no sólo valen, se imponen y son ineludibles.

No es momento de largas digresiones, pero sí de un paréntesis para recordar que el documental, como arte, ha de cumplir muchas funciones, desde la propiamente creativa hasta la comunicativa, cognoscitiva y valorativa, sin dejar a un lado la lúdica, la hedonística ni otras más; y que la inflación de una de ellas a expensas de la otra simplemente degrada la obra: el fin es comunicar bellamente, comunicar lúdicamente, comunicar creativamente, jugar cognitivamente, crear bellamente todas las combinaciones y permutaciones al unísono. He ahí la especificidad y el poder del arte. 


\section{Documental, modos de hacer y registro directo de la realidad}

Lo anterior nos permite vislumbrar adecuadamente que, al concebir el documental como arte (modo de hablar que significa "al referirnos a la clase de documentales realizados como arte") una de las maneras más firmes para "construir" una definición suya viene orientada por los modos de hacer; y que, si nuestra mirada aspira a ser amplia y honda a la vez, ha de extenderse y penetrar todo el universo fílmico en que se inscribe este documental, un universo de obras, propiedades y correlaciones, dijimos, no binario sino triádico en un orden primario, cardinal: documental, ficción y animación.

Oteamos un universo que pone en juego de contrastes, pero asimismo de complementación y otras relaciones, el registro directo, la representación (entendida en el sentido clásico, el que llega y se valida desde Aristóteles hasta la más moderna dramaturgia) ${ }^{5}$ y el dibujo animado o cine de animación (en cartones, imágenes informáticas y otros procedimientos). Aunque, y luego nos ocuparemos de recalcarlo, estos modos de hacer tengan, por un lado, modos derivados y modos subsidiarios $\mathrm{y}$, más aún, requieran otros complementos como las focalizaciones.

Nos hallamos ante tres modos de hacer predominantes, más o menos consagrados histórica y culturalmente, que marcan (subrayamos tan socorrido término) la realización de los filmes y, consiguientemente, con cierta relatividad y modalidades, la recepción de los mismos: el registro directo o inmediato de la realidad natural, positiva o dada de antemano (aunque, claro, sabemos que siempre construida social e individualmente); el registro de una representación (reconstrucción, imitación, construcción imaginaria) escénica (donde hay actores realizando acciones, hay escenarios y otros factores) y el registro de acciones realizadas por "seres" plásticos (dibujos estrictamente dichos, cuerpos plásticos como plastilinas y maderas, imágenes informáticas previamente diseñadas, entre otros), dibujos o "seres animados".

Esta tríada de recursos y construcciones, tomada en su conjunto, ayuda a discernir mejor ante qué nos hallamos. Sobre todo en casos dudosos o engañosos, como cuando uno u otro filme reconstruye o declara mostrar "realidades", cuando se vale a la vez de modos de hacer diversos o cuando asume intenciones y "marcas" prototípicas de uno de esos modos para ofrecernos el contrario: hablamos de esa diversidad constituida por biopics, filmes "basados en hechos reales", falsos documentales y filmes de ficción con la estilística del documental, de animados que se constituyen como memorias o crónicas y un largo etcétera.

Insistimos una vez más en que venimos hablando de un universo de obras y experiencias propiamente artísticas donde, ¿hay que decirlo?, cobra altísima validez el ámbito de formas, la recepción y disfrute estético mediante y a la vez encaminado

5 Tanto en la descripción aristotélica -la ¡Poética!, sí, con admiraciones todavía hoy- de hechos figurados por actores como en la más elaborada de Patrice Pavice como "reconstitución de algo diferente" (Véase el término Representación en su Diccionario del teatro. Dramaturgia, estética, semiología), fijándonos bien en sus comentarios sobre los términos idiomáticos del re-presentar francés y castellano y el Vor-steltung (poner delante) y Dar-stellung (poner ahí) alemanes. 
a las formas, a los modos de hacer y, con ellos, de asumir, recrear, crear, producir y ofrecer el mundo de imágenes a que nos enfrentamos.

\section{Un equívoco sobre imágenes: imágenes de la realidad versus ¿imágenes reales?}

Conviene recordar que el mundo del cine (y el de las artes) es un ámbito de creación (y recreación) de imágenes y no de su cacería y encierro para luego más o menos exhibirlas o liberarlas; por el simple hecho de que las imágenes no existen por sí mismas como entes (ni corpóreos ni incorpóreos), son siempre, en todo momento y circunstancia, un producto de estímulos (los cuales sí tienen cierta realidad) en nuestra mente o percepción ${ }^{6}$.

Existen sonidos porque tenemos oídos, es decir, audición. Existen imágenes visuales porque tenemos ojos, es decir, visión. Existen olores porque tenemos olfato. Por supuesto que sí existen el aire y sus vibraciones, y las ondas electromagnéticas y sus diversas frecuencias; pero sin oídos y visión que las reciban y transmuten en sonidos e imágenes gracias a nuestra compleja psiquis, no habría sonidos, imágenes visuales ni audiovisuales.

En el universo específico de las imágenes, el ser es ser percibido. El ser de las imágenes es ser percibido. Por ello, también pudiéramos decir que todo arte es virtual, ya que subsiste alentado por una potencialidad de producción de imágenes que devienen reales, actuales, con diversas resonancias en las diversas recepciones.

Pues sí, tenemos que abandonar toda concepción y definición del documental (y del cine y de cualquier arte) como registro de imágenes reales que, en fin de cuentas, no existen en ese sentido, como cuerpos o cosas, como entes en sí, que se presentan y deambulan conformando la realidad. Lo que el documental registra son ciertas zonas, propiedades o factores o, mejor, ciertas huellas de vibraciones acústicas (lo que percibimos como sonidos) y ondas electromagnéticas (lo que percibimos como visiones) de elementos de la realidad. Otras sensaciones, como los olores tan ansiados y ya experimentados por algunos, no cuentan mucho hasta hoy, permaneciendo aún fuera de nuestras artes y medios.

De uno u otro modo, nos hallamos con huellas o registros que, reproducidos y procesados en los equipos e instalaciones idóneas, producen en su público receptor imágenes más o menos correspondientes a los rasgos perceptibles de sus objetos.

6 Evidentemente, hablamos aquí sobre la realidad de las imágenes y no del mundo, que sería otro tema, al menos desde Parménides y el Ser, pasando por Aristóteles y Platón, la medieval (y persistente) batalla de los universales y todas las afirmaciones y negaciones (y dudas, para no olvidar a admirables filósofos como Kant, ya que después de todo Descartes sí llegó a afirmaciones tajantes con su extensión) sobre la materialidad o corporeidad del universo. La afirmación de la corporeidad o existencia objetiva del mundo ni es la misma ni implica la existencia objetiva de las imágenes; ni siquiera en el contexto de los arquetipos universales de Jung. Pero serían extensos temas. 


\section{Otro equívoco sobre imágenes: imágenes de la realidad versus ¿imágenes corporales?}

Del equívoco de las imágenes reales en el sentido expuesto, se genera o se emparienta el equívoco de las imágenes corporales aplicado al teatro y todas las artes escénicas para contrastarlas frecuentemente con las del cine y la audiovisualidad moderna ${ }^{7}$.

Todas las artes y, claro, también la literatura implican y se constituyen como tales gracias a las imágenes, la imago poética o artística. Hablar de pintura es hablar de imagen pictórica y no de lienzos, pigmentos y marcos de madera (aunque estos materiales se utilicen para lograr las imágenes pictóricas, o sin llegar a lograrlas como también para hacer otras cosas con ellos). Hablar de poesía es hablar de imagen poética, y no de palabras, puntos, papel y otros materiales (aunque ellos se utilicen para la creación de la imagen poética, como también y más comúnmente para otras cosas como el discurso coloquial o este mismo texto).

Hablar de teatro o de cualquier arte escénica es hablar de imagen teatral o imagen escénica, y no de personas, cuerpos y utilería (que se utilizan, valen para producir imágenes escénicas pero también para otras funciones y actividades). El teatro es teatro en la medida en que produce imágenes teatrales, desde la abundante parafernalia del teatro barroco y futurista hasta la más minimalista de un actor solo moviéndose en un espacio (donde hay un actor realizando acciones hay imágenes escénicas). Pero nunca se tratará de imágenes corporales sino de imágenes posibilitadas, creadas, logradas a partir de cuerpos moviéndose, de otros objetos, luces, etc., puestos ahí, delante de espectadores. Ver la obra de teatro es ver a Hamlet o Bernarda Alba, los personajes, y no los actores que los construyen; ver el ballet es ver a los cisnes o a Cascanueces, y no a las bailarinas y bailarines que construyen esas imágenes y personajes. Se trata de imágenes tan imaginales como las del cine o cualquier otro arte. Imágenes cuyo ser es ser percibidas y hacen absurdas una dicotomía o disparidad entre imágenes fílmicas (y televisivas, de la Internet, virtuales... imaginales) e imágenes corporales ${ }^{8}$.

Sería de lamentar que alguien entendiese en tan mal sentido la apelación al cine como arte de las imágenes o arte de las imágenes en movimiento: todas las artes son artes de (constituidas por y gracias a) imágenes así como el cine no es el único arte

$7 \quad$ Navegamos aquí por el antiquísimo tema del arte (las obras e imágenes artísticas) como ilusión, participación y una larga serie de concepciones a todo lo largo de la historia y del pensamiento filosófico, psicológico y estético: Platón, los eidos y la Caverna; Aristóteles, la mímesis y la representación; Plotino, los efluvios y la participación; con contundentes hitos de obligada recurrencia de principio a fin del siglo XX en autores como Ernest Gombrich, Erwin Panofski, Richard Wollheim, Regis Debray y (un inacabable) Otros.

8 Hoy surgen nuevos equívocos con el tema de la alta definición, como si esta superara las antiguas imágenes y modos de ver, lo verdadero y los modos de hacer del arte. ¿A quién se le ocurre que la fotografía invalidó a la pintura, o que los metales y cristales volvieron basura la arquitectura en madera y ladrillos; o que los instrumentos electrónicos y los sofisticados estudios digitales volvieron obsoleto el disfrute de una sonata de Bach, Beethoven, Chopin, Ravel, Albéniz Pau Casals en vivo en un salón? ¡Increíble falta de agudeza, cordura y, sobre todo, sensibilidad artística! La dialéctica del arte, diferente a la de otros ámbitos, tiende a ser acumulativa, o acumulativo-distributiva y no francamente eliminatoria. 
que proporciona imágenes en movimiento. Quizás la reina de las artes en este sentido sea la danza: ¡qué mayor esplendor dado por la imagen en movimiento, ser y sentido pleno de la danza!

No se trata de simples pruritos científicos (físicos, psicológicos) y, en general, teóricos (estéticos y epistemológicos). Entender el absurdo de hablar sobre "registros de imágenes reales" apuntala la comprensión de que no hay ni puede haber documental absolutamente objetivo, de que en todo documental (con mayor intensidad en los artísticamente concebidos) participan la subjetividad y la creatividad. Todo filme documental es en alguna medida una creación de su colectivo de realización y una recreación o asunción propia de los espectadores.

\section{Filmes de ficción y documentales entre contrarios y paradojas}

Se ha dicho que todo documental es un filme de ficción y todo filme de ficción es un documental, claro, desde una perspectiva siempre tan sagaz como a menudo extrema ${ }^{9}$.

¿Qué impide considerar al filme de ficción como un registro directo, inmediato, de lo que ocurrió en el escenario de representación, como una especie de documentalización en segundo grado, como documental de la representación? Exageremos un tanto, ¿y que todo filme de ficción lleva implícito, no siempre evidenciado pero imaginable por los duchos, las facetas de la realidad con que tuvo que vérselas, algo así como un posible making off? Evidentemente, la cordura, la precaución contra sagacidades que no conducirían a mucho más que a "brillantes" disquisiciones.

Con mayor sensatez y fecundidad puede postularse la premisa inversa, la de que todo documental es un filme de ficción, pues vale para llamar la atención sobre muchos órdenes de la realidad, de nuestro pensamiento, del arte y del cine: en primer lugar, que no existe una realidad absoluta, incuestionable al margen de nuestro accionar (y no sólo en las dimensiones infinitesimales estudiadas por Heisenberg, sino también en la nuestra); en segundo lugar, que cualquier acercamiento a la realidad y, sobre todo, en la actividad artística, está marcado por perspectivas, tendencias, selecciones y recreaciones, de modo que la captación, la exhibición y el reflejo (¡qué concepto tan peliagudo!) de la realidad en la obra artística resultarán siempre transfigurados o, en general, re-creados y nunca especular ni mecánico; y, en tercer lugar, consiguientemente, con los tonos de mayor trascendencia para nuestro tema, que todo documental implicará siempre selección, perspectivas, construcciones y otros factores desde el inicio hasta la edición final, e incluso en la distribución y exhibición mediante los más disímiles acondicionamientos de la recepción.

9 Es ya un tópico con diversas perspectivas y conceptualizaciones psicoanalíticas, socioculturales y semiolólgicas, desde la década de 190 hasta hoy, con hitos y autores muy notables como Christian Metz, Steve Neale y Roger Odin, cuyo ensayo Filme documentaire/lecture documentarisante nos ha inspirado en especial. 
La existencia de los llamados falsos documentales, en fin de cuenta filmes de ficción, ilumina muchas ideas sobre los documentales y la recepción fílmica acondicionada por circunstancias y por la competencia o enciclopedia del receptor.

No digamos categóricamente que todo documental es un filme de ficción, pero sí que en todo documental participa la ficción en cuanto recreación y recepción.

Asimismo, el equívoco subsanado y la premisa asentada más arriba sobre la inexistencia de imágenes reales (en el sentido de objetivas o dadas en la realidad positiva al margen de los humanos) y, por ende, el absurdo de hablar del documental como registro suyo (¡Increíble, definirlo como el registro de imágenes reales!), nos conduce a cierto paralelo con el cine de ficción (que tampoco registra imágenes reales): la distinción básica se produce entre el registro de elementos o factores sensibles a partir de lo ya positivamente dado o inmediato y el registro a partir de la representación... ambos en función de producir y recrear imágenes en los procesos de recepción.

Faltaría, entonces, subrayar los adjetivos predominante y focalizante además de los sustantivos o conceptos de realidad, reconstrucción o representación e imaginación.

La distinción básica entre filme documental y filme de ficción (que nosotros llamaríamos mejor filme de representación o de actuación, pero nos atenemos muy bien al uso) se da entre el predominio del registro directo o inmediato de y focalizante a favor de una realidad ya dada positivamente, ya dada en un ámbito pre-fílmico o no fílmico, y el registro de y focalizante de una representación, reconstrucción o creación de realidades (imaginales) que pueden o no estar inspiradas en realidades anteriores, pre-filmicas, o ser puramente imaginadas (aunque también sabemos que toda imaginación tiene como sustratos experiencias vividas).

En un ámbito, la preponderancia, la marca del modo de hacer que se vale del registro directo o inmediato y de lo inmediato (aunque fuese luego muy procesado) $y$, en el otro, primando la marca del modo de hacer según la representación y la reconstrucción.

\section{Documental, recepción documentalizante y el habiendo estado ahí}

Los modos de hacer histórica y culturalmente asentados no dejan de tener cierto correlato (a veces corroboración a veces contradicción) en ciertos modos de la recepción: recepción documentalizante, recepción ficcionalizante; donde parece que la recepción animada -difícil hallar o construir un término dada la diversidad de realización desde los dibujos en 2-D, pasando por las modelaciones y el stop motion hasta los actuales 3-D informáticos- tiene las "marcas" más distinguibles entre todas, en el sentido de que es más difícil dejar de ver un filme animado o, mejor, de animación, como tal o dejar de ver conscientemente sus recursos y clase de imágenes. Aunque... no nos extrañe nada. 
El documental clásico, prototípico, suele ir acompañado de una recepción en cuanto tal, hacemos del mismo una recepción documental o documentalizante. El filme de ficción clásico, típico, suele ir acompañado de una recepción ficcional o ficcionalizante; lo vivenciamos como historia de ficción ${ }^{10}$.

Tales recepciones conllevan muchas implicaciones dadas por nuestro saber $y$ disfrute de la obra, por sus modos de hacer, estructuras y formas generales, nuestros acondicionamientos artístico-institucionales y sociales hasta ciertas sensaciones relacionadas con el tiempo histórico y no histórico. Así, solemos vivenciar al documental o, mejor, nuestra recepción documental siente que estamos ante datos (personajes, acciones, lugares) que estuvieron ya ahí, que existieron ya (hace un tiempo, sea antiguo o muy reciente) en esa positiva realidad pre-fílmica registrada y que ahora se nos muestra. En fin, un fenómeno familiar al que se experimenta mirando un grupo de fotos tomadas como recuerdos.

El documental clásico articula los recursos y sensaciones del registro de la realidad dada o positiva con el sentimiento del haber o habiendo estado ahí ya antes.

Por su parte, vivenciamos el filme de ficción (como la novela o cualquier relato) como ante personajes, sucesos y lugares que van surgiendo, creándose o recreándose, que van estando ahí para nosotros en el momento en que los percibimos y hasta contribuimos a que tomen sus perfiles definidos. El filme de ficción clásico complementa los recursos y sensaciones de la representación (imitación, construcción y reconstrucción) con el estando ahí ahora conformándose y cobrando su "real existencia" ante mí.

El dibujo animado (en general, cine de animación), una vez más muestra la singularidad y firmeza de sus "marcas" al sintetizar la representación plástica con el estando ahí.

Volvemos a subrayarlo: matices, sutilezas, acondicionamientos socioculturales, relatividades en cierto grad. Pero se producen y funcionan.

\begin{tabular}{|l|l|l|}
\hline GÉNERO & $\begin{array}{l}\text { MODO DE HACER } \\
\text { PREDOMINANTE }\end{array}$ & VIVENCIA, ASUNCIÓN DE \\
\hline Documental & $\begin{array}{l}\text { Registro directo de la realidad } \\
\text { inmediata o positivamente dada }\end{array}$ & El habiendo estado ahí \\
\hline Ficción & Registro de una representación & Generalmente, el estando ahí \\
\hline Animación & $\begin{array}{l}\text { Registro de una representación } \\
\text { plástica }\end{array}$ & El estando ahí plásticamente \\
\hline
\end{tabular}

10 Por su importancia generalmente admitida y por su influjo sobre quien escribe estas líneas, volvemos a recomendar la lectura del trabajo de Roger Odín referido en nota anterior y en la bibliografía, no sólo pionero sino siempre uno de los más sagaces analistas de las perspectivas, actitudes y focalizaciones documentalizante y ficcionalizante. 


\section{Verdad, mentira, ilusión... y arte}

Debiera ser, pero no, en realidad aún no está del todo zanjado el problema de la verdad en el arte que, claro, no se identifica con el de la realidad o irrealidad de las imágenes ni con otros como la incorporeidad de las imágenes escénicas. Si las imágenes se actualizan y realizan siempre en la subjetividad, si todo arte es virtual y si todo arte escénico, en cuanto arte, es también virtual o medularmente imaginal; de ello no se deduce todo, más bien muy poco, sobre la multiplicidad de funciones y valores concomitantes al arte o sobre sus correlaciones con lo verdadero, lo extra-artístico u otras categorías ${ }^{11}$.

Ello no quita que sí exista claridad y vislumbres sobre muchos principios y carices de esta problemática. Por ejemplo, que es imposible identificar los mecanismos del saber y las verdades de las ciencias y el pensamiento lógico con los del arte, desde el silogismo a la aprehensión sensible. ¡Verdad de Perogrullo! Por ejemplo, que la obra más ficcional (evitamos el vocablo ficticia) puede implicar, conllevar verdades más hondas (espiritualmente) y con mayor información (datos sociales, culturales, etc.) que muchos tratados. Podemos ejemplificar con cierta novelística como la admirable Comedia Humana de Balzac y los no menos apreciables Episodios Nacionales de Benito Pérez Galdós como ejemplos cimeros, pero ello incumbe a todo el amplio universo del arte genuino ${ }^{12}$.

Más compleja y ricamente aún: la verdad del arte se relaciona también con su mundo de formas. Enunciado desde otra perspectiva: las formas son también parte, mejor dicho, se integran, conforman y propician la existencia y emergencia de las verdades del arte. Ello implica la posibilidad (de quienes tienen ojos para ver y oídos para oír) del descubrimiento y el sentimiento de las más hondas verdades incluso donde falte no sólo el discurso lógico u oral, la palabra, sino aun donde no aparezca la imagen figurativa, como en la música sinfónica y el arte abstracto.

$\mathrm{Y}$, aunque a primera vista luzca insólito, existen obras fílmicas ficcionales (y no sólo biografías, historias y otra clase de reconstrucciones basadas en hechos reales, sino obras ficcionales -filmes de ficción y de animación- de toda clase) mucho más verídicas (en su lógico-aristotélica correspondencia con lo real) y llenas de hondas verdades espirituales (saberes) que muchos documentales.

Aquí viene aflorando, imponiéndose el tema de los falsos documentales.

11 Por ello insistimos en las reflexiones apuntadas en los anteriores acápites sobre estos dos problemas.

12 Recordemos que el problema de la verdad también gana complejidad en sus correlaciones con las diversas corrientes, movimientos y estéticas, desde la más realista (e hiperrealista) a la más abstraccionista. Sin embargo, de uno u otro modo, desde las perspectivas más diversas, incluso contrarias, sagaces pensadores afirman la capacidad del arte de develar las más intrincadas esencias, dígase un Heidegger con la obra de arte como ámbito de confluencias, revelación y fundación del Ser; dígase George Gadamer con el juego artístico como juego ontológico, como precomprensión que coadyuva al ser humano a comprenderse y asumirse a sí mismo. 


\section{El Falso documental, las diferencias institucionales y... el principio de incertidumbre entre el haber estado y el estando ahí}

Si se nos puede ver o vivo o muertos a la vez en el espacio-tiempo, ¡Quien lo hubiera creído!, mucho más aún puede existir la incertidumbre entre el haber estado ahí y el estando ahí, y de eso precisamente se trata en el falso documental: nos entregan el estando ahí de todo relato ficcional, es decir, el mundo de imágenes construyéndose y viviendo ante nosotros ahora mismo; para convencernos, hacer que lo vivamos como que no es producto de una representación o una creación sino la plasmación de lo que antes estuvo ahí "de verdad", como el haber estado ahí antes en nuestro gran universo y no sólo en el mundo imaginal del filme.

Así está constituido el falso documental: Ficción por su modo de hacer y su mundo de imágenes predominantes; pero pretendido (ficticio, deseoso) documental mediante la búsqueda de una focalización, perspectiva, recepción instaurada desde el haber o habiendo estado ahí "realmente".

Todavía más, esta clase de filmes no agota con ello sus relatividades. También nos trae, entre otros, el interesante problema de su relación con los medios de comunicación y, por ende, de las diversas perspectivas posibles según las distintas instituciones. Y recordamos ahora aquellas ideas expuestas al inicio sobre el documental en sentido difuso, general o vago frente a su sentido más calificado y plenamente artístico.

Para los medios informativos o de comunicación, digamos televisión o Internet, el falso documental solo puede ser asumido en la programación informativa muy excepcionalmente, propuesto como obra sucedánea, vicaria o paliativa a falta de otras informaciones o de un documental propiamente dicho; o bien como parte de un espacio dedicado al arte fílmico, con las típicas presentaciones, comentarios o notas "críticas" del espacio televisivo o de la Red.

Un ejemplo consistente de falso documental con buenas intenciones informativas, y válido como sucedáneo o paliativo, puede ser Muelle de La Habana. Explosión del acorazado El Maine, realizado por George Mèlies en 1898.

En aquellos tiempos iniciales del cine, cuando aún no estaban desarrollados los géneros y cuando aún el cine ni siquiera estaba instituido como una de las artes, sino mirado como espectáculo de feria o simple divertimento, por un lado, y como agente informativo, por otro; Meliés recibe las noticias de la famosa explosión del buque El Maine, la cual desencadenó la llamada Guerra Hispano-Norteamericana.

Teniendo las informaciones pero no tomas oportunas ni registro alguno del inesperado hecho, Meliès reconstruye el suceso en la medida de lo posible, mediante "modelos" y una gran batea. Así, exhibe su "documento" fílmico-noticioso con las mejores intenciones, según parece o podemos presumir.

Desde la perspectiva periodística, he ahí una información "graficada", he ahí la "presentación audiovisual" de una noticia o reportaje y, ¿por qué no?, siempre que 
no haya intenciones engañosas o fraudulentas y la competencia o enciclopedia de los receptores les permita discernir bien el recurso informativo de "graficación" de noticias.

Muchos documentales, reportajes, crónicas y hasta noticias se auxilian de estos recursos de modelización, pero se nos hace patente dicho carácter de modelización o construcciones sucedáneas o paliativas ante la imposibilidad del registro directo, sin pretender darnos el sabor, función y recepción del auténtico falso documental. He ahí esos admirables documentales científicos donde se "modelan" tanto el universo como el microcosmos, y nos hablan de "teorías de cuerdas", genomas o ADN, desde la vieja graficación en láminas y plásticos hasta la moderna 3-D, incluyendo la animación.

Ahora bien, atendiendo otra dirección y espíritu, tampoco ignoramos esos documentales falsos, engañosos, aviesos (documentales falsos, no falsos documentales en su sentido artístico-cinematográfico), que con las más conscientes intenciones de engañar o gestados por las más trágicas doctrinas políticas, sociales o religiosas manipulan y falsean totalmente las realidades. Formalmente "verdaderos" documentales (en cuanto registro de ciertas realidades y acopio de datos convenientes); pero rechazables por su equívoco uso o nefastos por su engañosa manipulación de mentes y actitudes.

¿Qué decir, en tal asunto, sobre una obra tan significativa como El triunfo de la voluntad (1935), de Leni Riefenstahl? Bueno, habría que concederle su trascendencia en el orden de lo expresivo-formal, específicamente, y quizás también admitir-¿Quién lo sabe? - la sinceridad en su realización, nefasta pero sincera. Más falsos (embusteros) aún serían los cortos difundidos por los mismos nazis con las mediciones antropológicas y otros datos manipulados con el fin de "enseñar" la "inferioridad judía” o, desde otra perspectiva, la "superioridad aria". Asimismo, esos que pululan hoy al son de las "teorías de la conspiración" fabricando argumentaciones sobre autogolpes, sociedades secretas económico-místicas y otras conjuras.

No nos adentraremos en el profundo y extenso tema de "la verdad en el arte". Simplemente recordamos la existencia de documentales cuyos postulados o conclusiones son falsas... a veces con premeditados designios; y seguimos de inmediato hacia una clase de filmes que nos interesa sobremanera por sus peculiaridades artísticas, con el acuñado término de falso documental, falsedad que se ampara no en los referidos enunciados y doctrinas, sino precisamente en lo formal, lo imaginal, lo artístico, su modo de hacer: el predominio de la reconstrucción (incluyendo la actuación), de la ficción (o lo ficcional) o, en fin, de la simulación en su supuesto registro directo de realidades.

Aquí habríamos de volver a mencionar, al menos, la problemática de la verdad en el arte, en especial, las esenciales verdades y experiencias aportadas e inducidas por lo lúdico y las incisiones en la realidad promovidas por lo irónico y lo farsesco, entre otros aspectos y funciones.

El falso documental propiamente dicho sólo puede subsistir en las instituciones mediáticas o informativas, dijimos, en auxilio de la información, como documento expresivo o "medio didáctico". Carece de otro sentido en ellas en razón de su falsedad y por 
contravenir los fines y funciones de las mismas. Ya exceptuamos, claro está, los espacios dedicados al cine o al arte, entre otros, con sus debidos complementos informativos.

Los falsos documentales constituyen una clase de obras que hallan su verdadero sentido en instituciones artísticas y recepciones estéticas: en la institución arte o, mejor, en la institución cine propiamente dicha, o sea, arte cinematográfico, donde las funciones comunicativas, cognoscitivas y demás quedan subsumidas, sintetizadas en una general función y situación estética que da cabida y potencia el libre juego de formas y sentimientos (la ironía romántica y la burla aristofanesca o pantagruélica son relevantes en este tipo de filmes), la búsqueda de perplejidades y la ilusión.

No por excepción, al contrario, de modo general y con pleno sentido, los falsos documentales son obras cabalmente asimilables y hasta deseables por el arte, para la diversidad y enriquecimiento de un arte donde emergen como obras de ficción, como filmes de ficción que juegan y rejuegan con la perspectiva documentalizante del habiendo estado ahí: filmes en los que predomina el modo de hacer mediante la representación (actuación, etc., sin olvidar que "actuarse a sí mismo" es también actuar), mediante la reconstrucción ficcional pero en busca de la focalización o recepción del habiendo o el haber estado ahí.

Valga ahora un breve paréntesis sobre los biopics y otros filmes basados en hechos reales, que se ofrecen como reconstrucciones fidedignas; una clase de obras familiares en algunos aspectos a los falsos documentales y su pretensión de inducir un eficaz haber o habiendo estado ahí. Pero que, como sabemos, casi nunca logran el mismo grado de "verismo" o autenticidad de lo sucedido ante nosotros, por muchísimas razones que van desde la dramaturgia a los propios estilos de tomas y edición aparte de las ineludibles representaciones o recreaciones actuadas, sin que falten incluso razones de información o competencia en el saber de los espectadores. Normalmente asumimos los biopics y todas los filmes "basados en hechos reales" como reconstrucciones y, por ende, como cine de ficción por muy realistas y aun hiperrealistas que fuesen.

\section{Modos de hacer y modos de usar formas del documental}

El modo de hacer documentalístico y el modo de hacer ficcional se mezclan a menudo con toda conciencia aunque a veces con menos intencionalidad, que nada extraña ya a nuestros acondicionamientos como receptores, hasta el punto en que suele hacérsenos muy gustoso. Ahora bien, si se han realizado muchos estudios sobre los diversos modos y estilos del documental (y siempre habrá que remitir en primer lugar al citado libro de Bill Nichols), quizás escasean demasiado los referidos a los usos del modo de hacer documentalístico en el cine de ficción.

Sin ánimo de agotar modos y usos, vale la penar, al menos, apuntar la riqueza del recurso y del tema. 
En un extremo pudiera estar ese recurso puramente formal, cabalmente lúdico que, sin ánimo de engaño documentalístico, realiza la ficción imitando con ostentación de ello los procedimientos del documental o, quizás con mayor frecuencia, de los mass media (la entrevista, el reportaje, la crónica).

Tres buenos ejemplos son Toma el dinero y corre, realizado en 1969 por Woody Allen, alguien muy aficionado a estos recursos que repite a lo largo de su obra, en esta ocasión con espíritu francamente cómico (con acentuaciones farsescas y paródicas), al ofrecernos su crónica (rica en entrevistas) a su ficticio ladrón inepto Virgil; Todo por un sueño, realizado por Gus Van Sant en 1995, como crónica con abundantes referencias críticas, más bien irónicas y amargas no obstante la ligereza del relato, al mundo de los medios y las ambiciones superficiales o vacuas que pululan en éste; y El día que los mexicanos desaparecieron, corto realizado por de Sergio Arau y Yareli Arizmendi, lograda sátira sobre problemas étnicos y socioculturales en Norteamérica.

Tres filmes muy distintos por su sabor y estilo pero vinculados en el uso o, más bien, el remedo de ciertas formas del documental y, en general, de los mass media (entrevista, crónica, reportaje) sin pretensión de realidad documental cabal, sólo como juego formal para enriquecimiento de las formas y ámbito de la ficción.

En el otro extremo pudiera estar el auténtico documental construido indirectamente, buscando archivos y otras fuentes o, también, el documental (falso en cierto sentido, en cuanto registro) construido con afán de información verídica. Nos referimos, en el primer caso, a filmes como Now, realizado por Santiago Álvarez en 1965 y, en el segundo caso, el ya mencionado Muelle de La Habana. Explosión del acorazado El Maine, realizado por George Mèlies en 1898.

Puede objetarse que Now no es un filme de ficción y estamos hablando de simulaciones y usos de documentalística en el cine de ficción, y es verdad.

Mas, lo manejamos como paradigma de un tipo muy especial de documental que no realiza sus tomas, que no realiza su registro en la realidad inmediata o dada de modo directo, sino indirectamente, sirviéndose de documentos y fuentes diversas. Se trata de un registro, sí, de la realidad, pero basándose fundamentalmente, aprovechando la realidad dada mediante fotos, artículos periodísticos, y otros similares. Es un documental construido sobre la base de documentos previos. Ello, por lo demás, no es del todo raro. Grandes documentales, como El fascismo corriente, realizado por Mijaíl Romm también en 1965 y, otro del cine cubano, Y todavía el sueño, de Humberto Padrón, han utilizado documentos previos para construir total, casi total o considerablemente su propio documental. Lo que sucede en Now es que cobra protagonismo formal el uso de la foto fija (y el documento gráfico de prensa plana) y no el documento fílmico previo.

Como quiera que se mire, Now es un documental, pero con un grado de construcción y hasta de reconstrucción relativamente desacostumbrado en el documental cinematográfico, un grado de construcción que lo acerca incluso al video-clip y, sin identificarlo, a muchos procedimientos del falso documental. 
Un matiz diferente, un mayor grado de reconstrucción ofrece Muelle de La Habana. Explosión del acorazado El Maine, que sí pudiera considerarse desde cierta óptica como falso documental: filme de ficción en cuanto su modo de hacer mediante el registro de la construcción y reconstrucción total; pero buscando una recepción típica documentalizante (de lo habiendo ya estado en justa correspondencia con la realidad), aunque podemos asumir que con las mejores intenciones periodísticoinformativas (más que propiamente artísticas) en su caso.

Entre el extremo dado por filmes como los mencionados Toma el dinero y corre, Todo por un sueño y El día que los mexicanos desaparecieron, y el otro extremo dado por obras como Now o por los documentales construidos como Muelle de La Habana. Explosión del acorazado El Maine; tendríamos asimismo toda una gama de filmes de ficción que manipulan procedimientos y formas de la documentalística.

En esta gama, sobresale un filme como La primera carga al machete, realizado por Manuel Octavio Gómez en 1969, que simula de principio a fin las marcas del documental, filme muy creativo aunque muy coherente con una estilística (toda la de este director, la cubana en general y gran parte de la latinoamericana del momento) que debía mucho como escuela, corriente o, en fin, como estilística al modo de hacer, a las marcas o recursos del documental en el cine de ficción, a la fecundación de los recursos documentales en el cine de ficción, en fin, a un estilo o una estilística documental en la ficción.

La primera carga al machete simula, se vale, manipula artísticamente la crónica histórica (incluso con trovador), la granulosidad y matices (alto contraste del blanco y negro, por ejemplo) de los primeros tiempos del cine y de la fotografía que le precedió, falsas entrevistas y aun movimientos y composiciones escénicas más propias del viejo documental (y del viejo periodismo) que del cine de ficción, entre otros recursos muy acordes con tales procedimientos. Conforma la simulación artística de un documental realizado a la gesta de independencia, en tiempos coloniales, antes de la existencia del cine. Pero, nada de engaños a los receptores; todo lo contrario, la apelación a su saber y competencia para que disfruten un explícito juego artístico de lo que se sabe que es un filme de ficción, una total reconstrucción y actuación de realidades históricas reconstruidas, mostradas y puestas en intenso análisis dado su carácter de filme a la vez de ficción y de tesis.

En cierto sentido, lo contrario del falso documental, lo contrario del engaño de la recepción documental, incluso desarrollando la plena simulación de lo documental y un asunto histórico. Paradojas, rejuegos dialécticos que se suman a su grandeza como obra artística. Mientras el falso documental reconstruye hechos e imita al documental, escamoteando lo ficcional y buscando una recepción igual a la del haber estado ahí ya caracterizadora de lo documental. La primera carga al machete, lejos de negar el estando ahí a hora y todo lo relacionado con lo ficcional, lo hace explícito e intensifica. Salvo posibles excepciones, que no conocemos pero no queremos negar, será siempre asumido y disfrutado como filme de ficción que juega artísticamente con lo docu- 
mental. Ello se aviene muy bien con algo muy preciado por todo el quehacer de este realizador, hasta en sus filmes más convencionales, como el último, Gallego (1987): la presencia de lo histórico en la cotidianidad, la cotidianidad de lo histórico. Pero no nos detengamos más en lo que hemos traído a colación apenas como un ejemplo que, por lo demás, hemos considerado con mayor desarrollo en otras páginas.

Centrémonos ahora en esos filmes extremos en el aprovechamiento o uso de formas y marcas documentales en el cine de ficción, en los falsos documentales, esos que se proponen el puro engaño, para simplemente divertir, crear la incertidumbre o con fines otras veces menos precisos dentro de la amplísima gama desde el puro juego estético a la ilusión desconcertante.

Ofrecen un largísimo listado cuyo análisis eludimos ahora ya que ocuparía decenas de páginas. Mencionemos sólo algunos muy diversos como el reportaje de la CBS sobre La última tribu de Mindanao (1972), Fraude (Orson Welles, 1973), La seducción del caos (Basilio Martín Patino, 1991), Forgotten Silver (Costa Botes y Peter Jackson, 1995), El Proyecto de la bruja de Blair (D. Myrik y E. Sánchez, 1999), The Poughkeepsie Tapes (J. E. Doedle, 2009), Operación Luna (William Carel, 2002), Los primeros en la Luna (Aleksei Fedorchenko, 2005), La cuarta fase (Olatunde Osunsanmi, 2009) y El cazador de Trolles (André Øvredal, 2010).

Sin embargo, valdría la pena detenerse aunque fuese un instante en cierto tipo de falso documental que se encabalga más que otros entre la ficción y el documental, según se mire y se sepa: el del actuarse a sí mismo.

¿Qué decir de un filme como Suite Habana, prototipo del actuarse a sí mismos, realizado por Fernando Pérez en 2003? Como una suite audiovisual, sus secuencias y personajes desfilan ante nosotros con el más auténtico aire documental, ¿y quién no lo asume como tal? Habría que ser un espectador supercompetente para descubrir marcas de la realización que le permitieran dudarlo. Pero, entonces uno se entera, el propio director lo dice, que el filme responde a realidades esenciales de La Habana (de Cuba), a realidades vitales de los personajes, aunque las tomas no fueron del todo directas, naturales, sino que se pidió a los personajes que "hiciesen lo que acostumbran", "que se comportasen como si, como si, como si... estuviesen haciendo lo mismo de siempre" (Pérez, Suite Habana 2003).

$\mathrm{Y}$ uno toma conciencia de que es un filme de actuación, porque actuarse, representarse a sí mismos es también actuar. Y así uno se entera, sabe, adquiere en la enciclopedia personal el conocimiento de que es un filme de ficción, y comienza otro modo de disfrutarlo, el modo de disfrutar una ficción-actuación con el sabor de lo naturalmente registrado. Suite Habana queda como un filme de ficción que en nuestra ignorancia, en nuestra falta de sapiencia-competencia podemos disfrutar como auténtico documental, y que en nuestra mayor riqueza de datos y saber podemos disfrutar como espléndida ficción asimiladora y mimetizadota de lo documental.

Ya vimos que el problema de la veracidad (en el aristotélico sentido de correspondencia del discurso con lo real, en la perspectiva heideggeriana de abrir mundos o en 
cualquiera) es otro problema o está en otro plano: la verdad en el arte lo mismo que la verdad artística es otra cuestión y, con mayor sencillez, más directamente, el filme más ficcional puede inducir las verdades más hondas y complejas mientras que, a la inversa, un documental puede ser falso y mentiroso como los mayores embusteros. Aquí el problema tratado es el de la formalización y, más precisamente, el del género.

En esta misma línea, merecería un provechoso y deleitoso análisis aparte más detallando aún, Arirang (2011), ese interesantísimo filme en que Kim Ki-duk se actúa y filma a sí mismo, mezclando autorretrato y ficción. Sería provechoso y deleitoso.

Pero ya será, ahora los objetivos de este trabajo y el espacio apremian.

\section{Documental, animación e integridad estética de las recepciones}

Como quiera que se mire aunque, claro, sin tomarlo como absoluto metafísico, el género de animación o, abreviadamente, el animado sigue poseyendo las "marcas" genéricas (esas en las que ninguno creemos demasiado pero sí en alguna medida... y las necesitamos) más vigorosas y visibles. También se conjuga con las perspectivas y focalizaciones más consistentes.

El rejuego formal, de perspectivas y vivencias que realiza el cine de ficción con el documental en el falso documental es, si no imposible, casi imposible para la animación en virtud de nuestros comunes procesos de visualidad y hábitos receptivos generales. Dicho con otras palabras, es casi imposible no recepcionar y vivenciar la animación como creación plástica y, por ende, como construcción, recreación, la ficción y el estando ahí.

Dijimos dos veces casi, lo subrayamos, porque queremos pasar por inteligentes o cuerdos y no esquemáticos ni absolutistas. Pero sí, casi, casi imposible en las condiciones histórico-culturales actuales de la recepción artística, ni siquiera en filmes como Cosmópolis o, más radicalmente, Vals con Bashir, siempre que hagamos una recepción artística, específicamente cinematográfica.

Se puede utilizar la animación (y los efectos especiales, la 3-D y todos los recursos posibles) para elaborar informaciones, documentales magníficos: como recursos subordinados, en función de lo informativo para obras comunicativas, mediáticas y pedagógicas (medios de propaganda, de enseñanza, etc.), desde la institución y la perspectiva o focalización mediática o didáctica.

Pero la institución artística, la perspectiva o la focalización y, especialmente, la situación estética no se conforman ni ajustan con dicha perspectivas didácticas o mediáticas que, en todo caso, sub-sumen entre otras funciones; las instituciones, perspectivas y recepciones estéticas, artísticias y cinematográficas exigen la sensibilidad, recepción y disfrute de las formas, una aprehensión realizada (conscientemente) mediante las formas y, armónicamente, encaminada al disfrute de las formas, en su caso, las formas plásticas de la animación. 
Yo, ser insensible para la plástica, lo fílmico y lo estético; yo, empedernido fanático de lo conceptual y discursivo, paso por alto las formas y los sentimientos estéticos, y me concentro en la fábula, en los hechos contados, en lo que se dice y el discurso lógico -como si en el arte las formas no fueran también parte de lo que se dice, como si no estuviese ya resuelto el problema de que en el arte la forma es también contenido esencial- y pretendo ver Cosmopólis y Vals con Bashir como documentos históricos o periodísticos. ¿Clases de Historia escritas con "dibujos animados en función de medios didácticos", como dibujos que no me han valido más que cualquier otra clase de signos, como el lenguaje articulado o las maquetas plásticas de las clases de biología manejadas sólo para referir algo, sin altos valores por sí mismos, sin fines estéticos? ¿Puede suponerse posible esta recepción que, lejos de fijarse y detenerse situacionalmente en la animación y sus valores, sólo la mediatiza para instaurarse en el sentido lógico-conceptual, histórico-político del discurso, en la perspectiva historiográfica y periodística a expensas de la cinematográfica, artística y estética? ¿Podemos obviar o relegar la certidumbre de que nos hallamos, en primera instancia, ante recreaciones animadas?

Yo, lector poco sensible a lo poético, paso por alto las formas literarias y sólo veo la fábula (y el chisme) de Madame Bovary, y la leo, no como novela, sino como reportaje, crónica o anécdota de una infidelidad ocurrida. ¡Qué empobrecedora lectura! Otro Yo, receptor más agradecido a las formas, susceptible a la situación estética y amante de la literatura, ¿ cómo puedo dejar de satisfacerme en esas excelentísimos imágenes literarias, la construcción dramático-narrativa de la fábula, sus ritmos y otros valores del lenguaje; o sea, disfrutar la integridad de lo estético-literario con su conjunción de funciones que incluye pero no se reduce a lo comunicativo y cognoscitivo, sino también otras como la creativa, la lúdica y la hedonística? Entonces, percatarme de que todo lo que pasa, se cuenta, dice y aparece, lo hace mediante pero también en función de lo poético-literario.

Para el arte y sus instituciones se impone la perspectiva, la recepción de lo formal $y$, hablando de cine, la imposibilidad de prescindir de sus formas y modos de hacer (registro inmediato, representación y animación), esas que determinan primordial, cardinalmente lo genérico y son de imprescindible recepción para lo fílmico y artístico aunque no para lo historiográfico o lo periodístico.

Recepcionar Cosmópolis y Vals con Bashir, entre otros animados similares, como puros documentos y, más concretamente, como documentales, constituyen equívocos terminológicos y de perspectivas (equivalentes a recepcionar los diferentes filmes sobre Juana de Arco (los de Dreyer, Luc Besson y otros) o, más recientemente, The Better Angels (2014), de A. J. Edwards, con su re-creación de la atmósfera existencial del niño Lincoln, como documentales, porque documentan y reconstruyen hechos históricos.

Documental pudo asociarse con documento en primera instancia, pero de modo más maduro estéticamente con registro inmediato (aunque fuese el registro inmediato de un registro inmediato anterior). Todo documental constituye un documento y documenta algo; pero no todo documento ni todo lo que documente algo es un 
documental artística o cinematográficamente hablando. Un documental, un filme de ficción y un animado pueden documentar hechos, personajes y situaciones, como la tragedia o la comedia, un poema o un cuento, una pintura o una escultura. Mirar, disfrutar, valorar o recepcionar de cualquier modo una obra de arte desde la perspectiva de la veracidad de su asunto conduce no sólo a la mutilación o empobrecimiento de su integridad estética sino también a equívocos como mirar, apreciar y disfrutar una obra por la correspondencia de la veracidad de su asunto y su fábula con la realidad objetiva, a valorarla por su grado de reflejo especular de la realidad o por su mensaje a expensas de todos sus demás atributos.

Al supeditar la recepción de los filmes a la cualidad realista o no realista de sus temas, al supeditar la integridad del hecho fílmico a la veracidad de la re-construcción, tales recepciones ignoran no sólo que se trata de una re-construcción (y los mecanismos de ésta) sino también toda la problemática implicada en la realidad y la veracidad de lo artístico.

Imaginémonos mirando y dando importancia sólo al personaje de un retrato fotográfico sin percatarnos de las formas y cualidades generales de la obra fotográfica. Pero ello no es posible, porque el retrato de George Sand realizado por Nadar, el de Marilyn Monroe por Richard Avedon o el de John Lennon por Annie Leibovitz, no son George Sand, Marilyn Monroe ni John Lennon sino fotos (excelentes) de estos personajes; podemos verlos, evocarlos a ellos, pero sin tirar a la basura el hecho de que son fotografías suyas, o sea, visiones fotográficas sobre ellos. Nos vemos obligados a admirar, deleitarnos en sus cualidades fotográficas y ver a estos personajes sobre el fundamento de que se trata de re-creaciones, visiones fotográficas suyas, o no estamos haciendo una recepción fotográfica, artística ni estética, ni desde ninguna perspectiva cabal de esas obras fotográficas.

Recepcionar Vals con Bashir (para volver al ejemplo central) como documental (circunscribiéndonos a la fábula desnuda o priorizando sobre todo el documento que asumimos como plena y positivamente verídico) significa tirar a la basura las formas artísticas, no mirarlo ni cinematográfica, ni artística ni estéticamente, pues ello requeriría la asunción de sus formas animadas, como animados con asunto y fábula que recrean y mediante los cuales recepcionamos los hechos de Sabra y Chatyla. Resultaría una visión empobrecida como la del voyeur ante la Venus de Milo o los lienzos de Rembrandt, o como los insensibles ante la plástica fotográfica que sólo ven a los personajes Sand, Marilyn y Lennon; una visión simplemente consumidora del "objeto de representación" y no de la de la obra como totalidad; una visión quizás historiográfica, periodística o política, pero nunca una recepción cinematográfica que, quiérase o no, tiene que considerar las formas (la animación) y alcanzar lo demás mediante ellas ${ }^{13}$.

13 Este problema, que se conecta con muchos como el de la "doble visión" (visión, al unísono, de lo representado y los recursos de representación), la "belleza de lo feo" (la foto del ser más feo puede ser bellísima como foto porque no es el mismo ser sino una obra sobre él) y preferir la "verosimilitud sobre la veracidad" (la más verídica historia puede no ser verosímil, nada creíble; y una historia falsa puede ser totalmente verosímil) tiene ya respuestas tan 
No se trata de verdades o mentiras. Hay documentales manipuladores, tendenciosos y mentirosos; y hay filmes de ficción (y de animación) con verdades más profundas o tanto como ensayos filosóficos o tratados sociológicos.

De lo que sí no cabe duda es del vigor de las marcas formales y demás caracterizaciones genéricas del cine de animación y, por ello mismo, de la pobreza o mutilación dadas - al compararlas con una recepción estética, artística y cinematográfica- en una recepción documental de los animados a expensas de su plasticidad, aun de esos plenos de hondas verdades históricas y humanas que, de todos modos y quiérase o no, se establecen gracias a las mediaciones animadas, esos atributos que reclaman su disfrute y asunción para su logro definitivo.

\section{Concluyendo con puntualizaciones, generalizaciones y nuevas motivaciones}

Nos animó la necesidad de retomar diversas cuestiones sobre el cine documental, a partir de su propio deslinde y ciertas correlaciones con otra clase de filmes.

Trajimos a colación presupuestos e ideas estéticas y artísticas generales, así como necesarias referencias a otros medios y géneros, dada la necesidad y el propósito de realizar precisamente lo que suele faltar en reflexiones sobre el documental, el cine, el arte y lo estético: la rigurosidad conceptual y el pensar sistémico.

Hablamos del documental como ámbito del arte cinematográfico; del cine como una de las ramas del arte; y del arte como una de las manifestaciones de lo estético.

Partimos de la consideración de lo estético como actividad, facultad y situación caracterizadas por la aprehensión sensible de los fenómenos del universo. Pueden desprenderse muchas consideraciones dadas a lo largo de la historia de la Estética, que no son aquí objeto central de nuestra reflexión, pero nada se pierde con rememorar de pasada lo siguiente: lo estético es una actividad y facultad propiamente humanas, caracterizadas por la situación y aprehensión sensibles y sentimentales (sensibilidad y sentimiento que, humanos al fin, nunca están desvinculados de lo conceptual, y lo social); $y$, asimismo, junto a la fe, como las dos únicas esferas de lo social y lo humano sin precedentes en la vida animal. Se trata de dos premisas que pueden ser asumidas desde las más diversas perspectivas filosóficas o de pensamiento, con los argumentos y perfiles apropiados para cada perspectiva.

Si lo estético compete a lo más universal, a cualquier fenómeno y situación posible asumida por el ser humano; el arte es una esfera privilegiada de dicha actividad y situación.

antiguas como las del Aristóteles y sus reflexiones sobre la fábula, en todo caso núcleo, motivo fundamental o esqueleto de la obra pero nunca ni toda la obra ni lo decisivo en su valía o propiedades estéticas (claro, este no podía ser lenguaje de aquel entonces). ¿Qué mejor argumento que el propio teatro griego, o las comparaciones entre las versiones de una misma historia? En el arte siempre se trata de formas y mediaciones y toda fábula, objeto y elemento se halla mediado y mediatizado por ellas. 
Definimos al arte, más que a partir de determinadas cualidades de sus obras y productos (claro que se implican o no pueden ser ignorados), desde su perspectiva sociocultural: al arte como el modo de actividad humana institucionalizada en mayor o menor grado conforme a fines estéticos, para propiciar o favorecer la plena situación estética. Como quiera que se mire, lo estético o, más específicamente, la situación estética y las instituciones o, como podemos oír con mayor elegancia y revuelo, la Institución Arte.

Pero, ello resulta empobrecedor si nos quedamos "congelados", circunscriptos a los planos sociológicos y pragmáticos de la Institución. Para entender cabalmente qué es el arte, sus característica, funciones y productos, hemos de considerar siempre su plano ontológico, el ser de la obra de arte, de todas y cada una de ellas.

Podemos asegurar que todo aquello que alguna vez las instituciones, la sociedad, la cultura ha considerado "arte" ofrece, de uno u otro modo, una estructura significante o, más a nuestro gusto, un universo de imágenes, un mundo imaginal; $\mathrm{y}$, a la inversa, toda estructura significante o mundo de imágenes que en algún momento y lugar halla sido considerada como arte, lo ha sido gracias a su acogimiento institucional en cuanto tal. Institución y mundo imaginal ya sea en la pintura, la arquitectura, la poesía propiamente dicha o en las artes "más complejas" (¿existe esa graduación?) como la ópera, el cine y todas las audiovisuales.

Institución y mundo de imágenes, nada más simple y más complejo. Ello explica, simple y complejamente, por qué la televisión e Internet no son "arte" y el cine sí. Cuestión institucional, de producción, fines y otros mecanismos. Ello explica por qué diferentes obras de un mismo tipo de estructuras sígnicas y de mundos imaginales resultan ser vivenciadas y asumidas unas como arte y otras no. Por ejemplo, este escrito no es poesía, cualquier sonido no es música y cualquier filmación no es cine.

Podríamos reflexionar mucho al respecto, pero no figura en nuestro objetivo central. Sólo lo dejamos ya asentado aquí como otra de las premisas que permiten entender qué es el cine.

También partimos de una definición rigurosa y actualizada del cine como arte de la sucesión coherente de imágenes audiovisuales recreadas mediante una superficie y una matriz; donde ningún término es suficiente: todos necesarios y, como conjunto, sí suficientes.

Arte, sucesión coherente, imágenes audiovisuales, superficie y matriz; todo ello debidamente justificado, incluyendo lo de la sucesión en vez del movimiento, la audiovisualidad (incluso en breve y transitoria era "muda"), la superficie y la matriz (una necesaria entre una gama diversa).

Y los géneros cinematográficos como géneros de un arte específico; del cine como subuniverso del arte y al arte como subuniverso de lo estético.

No se trata de los géneros cinematográficos como simples sistemas de signos de todo el universo que incluye artes y medios, porque soportan mayores determinaciones. En su correlación con filmaciones y géneros periodísticos o mediáticos; el 
cine y los géneros cinematográficos viven semejanzas y diferencias análogas a las del periodismo con relación a la novela (toda la narrativa, la poesía y la literatura propiamente dicha), donde el papel periódico es un medio más amplio que admite en sus página la publicación de un poema y otras obras literarias, pero admite e incluso está mayormente destinado a otra clase de escritos o "mensajes".

Por ello hemos rechazado también las supuestas clasificaciones genéricas al uso que, ya desde un principio, muestran su incoherencia lógica (criterio temático en un caso, estilístico en otro, de producción en otro, de espíritu y así sucesivamente: de guerra, de suspenso, cómico, animado, por ejemplo) además de su improcedencia por cuanto dejan siempre la extensión del concepto definido mayor que la de los objetos con que se definen.

Asumimos, entonces, con nuevos argumentos, experiencias y talante, la tradición aristotélica de los modos de hacer, como criterio primordial, aunque la complementamos también con las actitudes y perspectivas de recepción (de lo cual es un pionero Roger Odin); y, así, nos atuvimos primordialmente a la producción mediante el registro inmediato o directo de la realidad pre-filmica o ya dada, el registro de la recreación o reconstrucción (la actuación o representación mediante) y el registro de los dibujos, diseños o modelos animados; como se observa aquí:

\begin{tabular}{|c|c|c|}
\hline GÉNERO & $\begin{array}{l}\text { ATRIBUTO FUNDAMENTAL: } \\
\text { MODO DE HACER } \\
\text { PREDOMINANTE }\end{array}$ & $\begin{array}{l}\text { CORRELATO O ATRIBUTO } \\
\text { SECUNDARIO: FOCALIZA- } \\
\text { CIÓN O VIVENCIA }\end{array}$ \\
\hline Documental & $\begin{array}{l}\text { Registro directo de la realidad } \\
\text { inmediata o positivamente dada }\end{array}$ & El habiendo estado ahí antes \\
\hline $\begin{array}{l}\text { Ficción } \\
\text { (incluyendo } \\
\text { los falsos } \\
\text { documentales) }\end{array}$ & Registro de una representación & $\begin{array}{l}\text { Generalmente, el estando } \\
\text { ahí ahora. } \\
\text { En falsos documentales, como } \\
\text { excepción, se induce el habiendo } \\
\text { o haber estado ahí antes. }\end{array}$ \\
\hline Animación & $\begin{array}{l}\text { Registro de una representación } \\
\text { plástica }\end{array}$ & $\begin{array}{l}\text { El estando ahí plásticamente } \\
\text { ahora }\end{array}$ \\
\hline
\end{tabular}

De modo que, podemos precisar las siguientes definiciones, con considerable rigor teórico que, entre otros órdenes, considera sistémicamente los géneros y otros fenómenos fílmicos: 
El documental es la forma fílmica caracterizada por el predominio del registro de la realidad inmediata o positivamente ya dada y la inducción de una recepción del mundo de imágenes de la obra como el de un haber o habiendo estado ahí antes.

El filme de ficción es la forma fílmica caracterizada por el predominio del registro de una reconstrucción o representación de realidades y, típicamente, por la inducción de una recepción del mundo de imágenes de la obra como el de un estando ahí ahora aunque, excepcionalmente, también como el de un haber o habiendo estado ahí antes.

El filme de animación será la forma fílmica caracterizada por el predominio del registro de una reconstrucción, creación o representación plástica de realidades y la inducción de la recepción del mundo de imágenes de la obra como un estando ahí (plásticamente) ahora.

Cine documental, cine de ficción y cine de animación constituyen los tres géneros primordiales, cardinales, básicos, fundamentales. Basta de adjetivos. Se entiende bien. Los demás "géneros" (entendidos así en cuanto, es verdad, nadie lo niega, han llegado a conformar históricamente una especie de "generalidad", grupo o conjunto) son realmente sub-generos supeditados, incluidos en uno de estos grandes y más estables o definitivos géneros cardinales. El cine del oeste, el cine cómico, el cine musical o el cine de guerra, entre otros, por ejemplo, son básicamente subgéneros del cine de ficción, aunque se dé por sobreentendido. Como norma, los habitualmente llamados "géneros" son en realidad subgéneros del género de ficción; aunque, por supuesto, hay documentales musicales, de guerra y de amor, así como filmes animados históricos, musicales, y un largísimo si no ilimitado etcétera.

La concepción trigenérica fundamentada en los modos de hacer posibilita además comprender otros muchos fenómenos del cine -cuando decimos cine decimos arte cinematográfico- como los híbridos y los lúdicos rejuegos estéticos por el estilo del falso documental; como por qué las conocidas versiones fílmicas sobre Juana de Arco son filmes de ficción (históricos) y no documentales, o animados como Persépolis y Vals con Bashir son filmes de animación (históricos, políticos) y no documentales... a menos que uno violente las perspectivas y recepciones disolviendo la situación y aprehensión artístico-cinematográfica y estética en pos del contenidismo temático, en desmedida cacería del "que se dice" (conceptualmente) a expensas de "cómo se dice" y, por ende, del "qué se dice” emocional, sentimental, estética, artística y fílmicamente.

Ahora nos gustaría dejar sentadas algunas sugerencias o propuestas muy imbricadas con lo anterior, aspirantes a un nuevo diálogo con ellas.

He ahí, entre otras, las correlaciones entre novela y cuento respecto al filme de ficción y la animación (donde también los comics jugarían gran papel); asimismo a las correlaciones entre ensayo (literario, por supuesto) y documental artísticamente entendido; sin olvidar esa interesante zona de las memorias y la literatura testimonial respecto lo mismo al documental que a la ficción. Finalmente, sólo sembremos también sugerencias sobre deslindes, conceptos y fenómenos de equivalencias, divergencias y divergencias mediáticas y propiamente artísticas. 
¿Podemos afirmar tajantemente, como sí lo creemos nosotros, que ciertas denominaciones, formas y supuestos géneros de los informativos y mass media no competen, como géneros y formas independientes, al arte cinematográfico, al cine? Más específicamente, ¿que las formas entrevista, reportaje, crónica, noticia, entre otras del mundo informativo audiovisual (televisión, Internet) no son formas autónomas ni propiamente genéricas del cine sino de la televisión (y ciertas modalidades de Internet)? Es decir, ¿qué la forma propiamente cinematográfica es el documental, como compleja forma artística que subsume o incorpora estas formas informativas: documental construido básicamente mediante la entrevista; documental construido mediante el reportaje?

Volvemos a parangones fecundos: las semejanzas y diferencias se comportan análogas a las del periodismo y la literatura. La entrevista, el reportaje, la crónica y demás formas periodísticas pueden ser elegantes, bellas y demás calificativos estéticos, pero cualidades siempre subsumidas, subordinadas a lo informativo. Con tal talante, no constituyen poesía ni literatura propiamente dicha. Sin embargo, una buena novela puede incorporar epístolas, entrevistas, noticias, crónicas y otros recursos (incluso verídicos y no sólo imaginados) a su conformación novelística, a su ser propiamente literario. La forma, el género literario es la novela, es decir, la narrativa y no la entrevista, crónica, etc. Periodismo y literatura tienen sus medios, modos, fines e instituciones.

Entre la infinidad de ejemplos posibles, surgen de inmediato La delgada línea azul (1988) de Errol Morris y Canciones para después de una guerra (1971) de Basilio Martín Patino.

La delgada línea azul se erige como paradigma de documental construido en base a entrevistas - con muy breves secuencias reconstruidas y reiteradas del hecho investigado y algunas otras pocas más bien simbólicas o sugestivas- que también, a todas luces, rebasa la función puramente comunicativa, pleno de una sutil gama emocional (ironía, cinismo, indignación, juicio crítico) y en un rico juego formal que no olvida luces, atmósfera sonora ni la sobresaliente edición. La rica finalidad estética, la rica complejidad y multiplicidad de funciones, hacen trascender la predominante, casi total forma entrevista, la subsumen en una rica recepción artístico-documental. Empobrecidamente mirado, periodismo mediante entrevistas complementadas por algunos otros recursos. Ricamente mirado, documental cinematográfico que aprovechas la forma "entrevista".

Canciones para después de una guerra ofrece retos mayores en nuestro tema. No los dos términos de La delgada línea azul (entrevista y documental) sino tres: crónica, documental, musical. El filme constituye una crónica sobre España y su Guerra Civil, más aún, sobre tradiciones, idiosincrasia, música, hechos, personalidades ibéricas. La forma crónica validada, utilizada para la construcción del documental y, por añadidura, el musical.

En su fecunda y agradable idea de estructurar el filme mediante la música y documentos musicales en su devenir histórico, Patino demuestra fehacientemente que 
el musical no es privativo de la ficción (como también lo han demostrado muchos filmes de animación); sino más allá, a ver que el musical no es siquiera, con toda propiedad, un género sino un subgénero habitual en el cine de ficción pero también posible subgénero del documental y del animado.

Quedamos aquí con estos ejemplos de posibles reflexiones en torno a cuestiones del cine y sus géneros, sobre las que nuestras concepciones sistémicas de cine, géneros y documental -en sus justas correspondencias con lo estético y lo artístico, lo institucional y lo imaginal- ofrecen guías y vislumbres fundamentados y coherentes.

Queda nuestra invitación a analizar todo lo anterior en su conveniente dialéctica desde lo estético a lo artístico (y lo mediático); desde lo artístico a lo cinematográfico y desde aquí a lo genérico-cinematográfico; sin dejar de andar también en sentido inverso.

\section{Referencias}

Altman, Richard. Los géneros cinematográficos. Barcelona: Paidós, 2000. Medio impreso. Aristóteles. Obra Completa. Ed. Miguel Candel. Madrid: Gredos, 2011. Medio impreso. Arnhein, Rudolph. El cine como arte. La Habana: Arte y Literatura, 1981. Medio impreso. Aumont, Jacques et al. Estética del cine. Espacio fílmico, montaje, narración, lenguaje. Barcelona: Paidós, 1985. Medio impreso.

Barthes, Roland: Lo obvio y lo obtuso (Imágenes, gestos, voces). Barcelona: Paidós, 1995. Medio impreso.

Berger, René et al. Arts et moyens de communication. Lausanne: Institute d'Etude et de Recherche en Information Visuelle, 1984. Medio impreso.

Bettetini, Gianfranco. Producción significante y puesta en escena. Barcelona: Gustavo Gili, 1987. Medio impreso.

Bordwell, David. El significado del filme. Barcelona: Paidós, 1995. Medio impreso.

Bordwell, David y K. Thompson. El arte cinematográfico. Barcelona: Paidós, 1995. Medio impreso.

Borrás, J. y A. Colomer. El lenguaje básico del filme. Barcelona: Nido, 1997. Medio impreso.

Calabrese, Omar. El lenguaje del arte. Barcelona, España: Paidós, 1989. Medio impreso.

Cassetti, Francesco: Teorías del cine (1945-1990). Madrid: Cátedra, 1994. Medio impreso.

Chion, Michel. La audiovisión. Barcelona: Paidós, 1994. Medio impreso.

Company Ramón, Juan Miguel. El trazo de la letra en la imagen. Texto literario y texto fílmico. Madrid: Cátedra, 1987. Medio impreso.

Daicich, Osvaldo: Apuntes sobre el Nuevo Cine Latinoamericano. Entrevistas a realizadores latinoamericanos. La Habana: Fundación del Nuevo Cine LatinoamericanoEscuela Internacional de Cine y Televisión de San Antonio de los Baños, 2004. Medio impreso. 
Danto, Arthur C. Después del fin del arte. Barcelona: Paidós, 1999. Medio impreso. ---. El abuso de la belleza. La estética y el concepto de arte. Barcelona: Paidós, 2006. Medio impreso.

Darley, Andrew. Cultura digital. Espectáculo y nuevos géneros en los medios de comunicación. Barcelona: Paidós, 2002. Medio impreso.

Debray, Regis. Vida y muerte de la imagen. Historia de la mirada en Occidente. Barcelona: Paidós, 1994. Medio impreso.

Dickie, George. El Círculo del Arte. Barcelona: Paidós, 2005. Medio impreso. Eco, Umberto. La definición del arte. México: Roca, 1990. Medio impreso. Eisenstein, Seguéi. Eisenstein. La Habana: ICAIC, 1967. Medio impreso. Formaggio, Dino: Arte. Barcelona: Labor, 1976. Medio impreso.

Gadamer, Hans Georg: Hermenéutica, estética e historia: Salamanca: Sígueme, 2013. Medio impreso.

---. Verdad y Método I. Fundamentos de una hermenéutica filosófica. Salamanca: Sígueme, 1977. Impreso.

García Jiménez, Jesús. Narrativa audiovisual. Madrid: Cátedra, 1996. Medio impreso. Garroni, Emilio. Proyecto de semiótica. Mensajes artísticos y lenguajes no verbales; problemas teóricos aplicados. Barcelona: Gustavo Gili, 1975. Medio impreso.

Gaudreault, André y François Jost. El relato cinematográfico. Barcelona: Paidós, 1995. Medio impreso.

Goldsmith, David A. El documental. Entrevista en exclusiva a quince maestros del documental. Madrid: Océano, 2003. Medio impreso.

Gombrich, Ernest: Arte e ilusión. Barcelona: Gustavo Gili, 1982. Medio impreso.

---. Meditaciones sobre un caballo de juguete. Barcelona: Seix Barral, 1968. Medio impreso. Goodman, Nelson: Los lenguajes del arte. Barcelona: Seix Barral, 1976. Medio impreso. Gubern, Román. La mirada opulenta. Exploración de la iconosfera contemporánea. Barcelona: Gustavo Gili, 1987. Medio impreso.

Hegel, G. W. F. Estética. Barcelona: Península, 1989. Medio impreso.

Iser, Wolfgang. El acto de leer. Teoría del efecto estético. Madrid: Taurus. 1987. Medio impreso.

Jarvie, I. C.: Sociología del cine. Madrid: Guadarrama, 1974. Medio impreso.

Jauss, Hans Robert. Experiencia estética y hermenéutica literaria. Madrid: Taurus, 1986. Medio impreso.

Kagan, Moisés. "La estructura de la forma artística”. Criterios 3/4 (jul-dic 1982): 33-48. Medio impreso.

Kuleshov, Lev. Tratado de realización cinematográfica. Buenos Aires: Futuro, 1956. Medio impreso.

López Quintás, Alfonso. Estética de la creatividad. Juego, arte, literatura, Barcelona: Promociones Publicaciones Universitarias, 1987. Medio impreso.

---. La experiencia estética y su poder formativo. Estella: Verbo Divino, 1991. Medio impreso. 
Lotman, Yuri. Semiótica del cine y problemas de la estética cinematográfica. México: UNAM, 1979. Medio impreso.

Maqua, Javier. El docudrama. Fronteras de la ficción. Madrid: Cátedra, 1992. Medio impreso.

Martin, Marcel. La estética de la expresión cinematográfica. Madrid: Rialp, 1962. Medio impreso.

Metz, Christian. Ensayos sobre la significación en el filme. Buenos Aires: Tiempo Contemporáneo, 1972. Medio impreso.

---. Lenguaje y Cine. Barcelona: Planeta, 1973. Medio impreso.

Mitry, Jean. Estética y psicología del cine. Madrid: Siglo XXI, 1978. Medio impreso.

Moscardó Guillén, José. El cine de animación en más de 100 largometrajes. Madrid: Alianza, 1997. Medio impreso.

Mukarovsky, Jan: Escritos de estética y semiótica del arte. Barcelona: Gustavo Gili, 1977. Medio impreso.

Neale, Steve. Genres. London: British Film Institute, 1981. Medio impreso.

Nichols, Bill. La representación de la realidad (Cuestiones y conceptos sobre el documental). Barcelona: Paidós, 1997. Medio impreso.

Odin, Roger: "Filme documentaire/lecture documentarisante". Cinéma et Réalités. Comp. J.L. Lyant y R. Odin. Cierec: Université de Saint-Etienne, 1984. Medio impreso.

Ortega y Gasset, José. La deshumanización del arte. Madrid: Revista de Occidente, 1961. Medio impreso.

Pavis, Patrice. Diccionario del teatro. Dramaturgia, estética, semiología. La Habana: "R", 1988. Medio impreso.

Pudovkin, Vsevelov. Argumento y montaje, bases de un filme. Buenos Aires: Futuro, 1956. Medio impreso.

Ricoeur, Paul: El conflicto de las interpretaciones. Ensayos de hermenéutica. Buenos Aires: La Aurora, 1976. Medio impreso.

---. Teoría de la Interpretación. Discurso y excedente de sentido. México: Siglo XXI, 1999. Medio impreso.

Rojas Bez, José. Artes, cine, videotape: Límites y confluencias. Holguín: Dirección Municipal de Cultura, 1987. Medio impreso.

---. De cine, Tv y otros medios. Monterrey: Arbor (Universidad Autónoma de Nuevo León), 2000. Medio impreso.

---. El cine por dentro. Puebla: Universidad Iberoamericana - Universidad Veracruzana, 2000. Medio impreso.

---. El cine entre las artes. Reflexiones estéticas sobre cine. La Habana: Pueblo y Educación, 2006. Medio impreso.

---. "Estética y sociología de la relación cine-video". Cuadernos Cinematográficos 9 (1995): 39-54. Valladolid: Universidad de Valladolid. Medio impreso. 
---. Pasaje al arte del cine. Guadalajara: Universidad de Guadalajara, 2013. Medio impreso.

---. Audiovisualidad, artes y cultura contemporánea. La Habana: Pueblo y Educación, 2014. Medio impreso.

Romaguera i Ramió, Joaquín y Homero Alsina Thevenet (Eds.). Textos y manifiestos de cine. Estética. Escuelas, movimientos, disciplinas, innovaciones. Madrid: Cátedra, 1989. Medio impreso.

Ruiz, Raúl. Poética del cine. Santiago: Sudamericana. Medio impreso.

Ruíz Jiménez, Antonio G. El cine: ¿Muerte o transfiguración? (La disolución del lenguaje cinematográfico en el universo audiovisual). Sevilla: Comunicación Social, 2005. Medio impreso.

Sánchez Biosca, Vicente. Cine y vanguardias artísticas. Conflictos, encuentros, fronteras. Barcelona: Paidós, 2004. Medio impreso.

Sánchez Noriega, J. L. Historia del cine. Teoría y géneros cinematográficos, fotografía y televisión. Madrid: Alianza, 2002. Medio impreso.

Sánchez, Vicente: Cine y vanguardias artísticas. Barcelona: Paidós, 2004. Medio impreso. Schaeffer, Jean-Marie. La imagen precaria. Madrid: Cátedra, 1990. Medio impreso. Sontag, Susan: Estilos radicales. Madrid: Santillana, 1997. Medio impreso.

Souriau, Etienne. L'Universe Filmique. París: Flammarion, 1953. Medio impreso.

Stam, Robert. Nuevos conceptos de la teoría del cine. Barcelona: Paidós, 1992. Medio impreso.

Stepan, Fedor. El teatro y el cine. Madrid: Taurus, 1960. Medio impreso.

Tarkovski, Andrei. Esculpir en el tiempo. Madrid: Rialp, 1991. Medio impreso.

Terukina, Ichi. Cinegramas. Estudio preliminar de la toma cinematográfica. Lima: Briznas, 1996. Medio impreso.

---. El río de las imágenes. Del cinegrama a la toma. Lima: Asociación Peruano Japonesa - Pedagógico San Marcos, 2004. Medio impreso.

Torreiro, Casimiro y Josetxo Cerdán (Eds.). Documental y vanguardia. Madrid: Cátedra, 2004. Medio impreso.

Urrutia, J. y P. Esteve. Contribuciones al análisis semiológico del filme. Valencia: Fernando Torres, 1976. Medio impreso.

Vanoye, François y A. Goliot-Lété. Principios de análisis cinematográfico. Madrid: Abada, 2008. Medio impreso.

Velazco, Arnulfo Eduardo. El placer de las imágenes. Estudios sobre algunas formas de comunicación visual. Guadalajara: Universidad de Guadalajara, 2001. Medio impreso.

Wallis, Brian (Ed.). Arte después de la modernidad. Nuevos planteamientos en torno a la representación. Madrid: Akal, 1996. Medio impreso.

Wolf, Sergio. Cine/Literatura. Ritos de pasaje. Barcelona: Paidós, 2001. Medio impreso. Wollheim, Richard: El arte y sus objetos. Barcelona: Seix-Barral, 1972. Medio impreso. 
Wyver, John. La imagen en movimiento. Aproximación a una historia de los medios audiovisuales. Valencia: Filmoteca Valencia, 1992. Medio impreso.

Zavala, Lauro. Elementos del discurso cinematográfico. México: Universidad Autónoma Metropolitana, 2003. Medio impreso.

---. (Coord.). Reflexiones teóricas sobre cine contemporáneo. México: Secretaría de Educación, 2011. Medio impreso.

Recibido: 07 noviembre 2013

Aceptado: 10 septiembre 2015 